\title{
Ammonia and COD removal from landfill leachate using MAP precipitation method
}

\author{
Kuleyin A. ${ }^{1}$, Yeni $0 .{ }^{1}$, Sisman Y. ${ }^{2}$ \\ ${ }^{1}$ Engineering Faculty, Environmental Engineering Department, Ondokuz Mayıs University, 55220 Atakum, Samsun, Turkey \\ 2Engineering Faculty, Geomatic Engineering Department, Ondokuz Mayıs University, 55220 Atakum, Samsun, Turkey \\ Received: 22/02/2019, Accepted: 06/07/2020, Available online: 28/07/2020 \\ *to whom all correspondence should be addressed: e-mail: akuleyin@omu edu.tr \\ https://doi.org/10.30955/gnj.003088
}

\section{Graphical abstract}

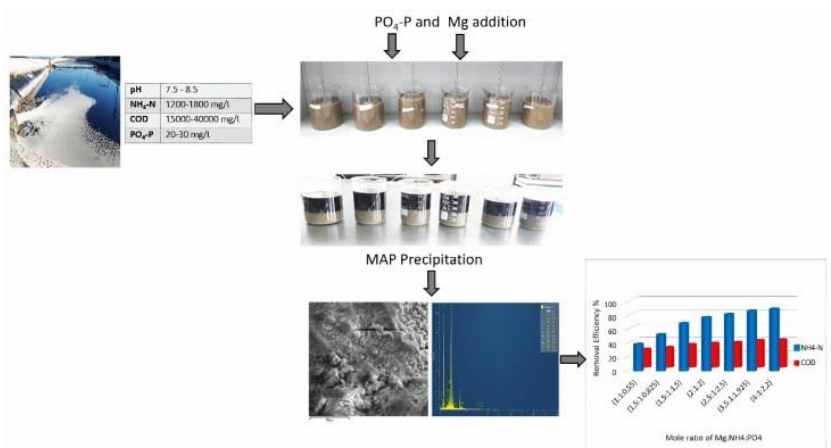

\begin{abstract}
Most of the major cities in our country are opposed to the problem of water pollution due to the uncontrolled leachate resulting from the decomposition of solid wastes in irregular landfills. The waste waters that have high nitrogen content such as leachate cause various problems like eutrophication. In this study; the preliminary treatment of leachate which formed on the landfill site storing solid wastes of Samsun Metropolitan Municipality by MAP (Magnesium ammonium phosphate) precipitation was examined. For this purpose, optimization of the parameters that affecting the MAP precipitation was performed and the conditions for optimum removal efficiency were investigated. As a result of MAP precipitation, various mole ratios were tested with the aim of providing the best ammonia removal efficiency. The maximum ammonia removal was found to be $90.63 \%$ at $\mathrm{pH}$ 9.5 and at $\mathrm{Mg}: \mathrm{NH}_{4}: \mathrm{PO}_{4}$ ratio of $4: 1: 2.2$. At this conditions the ammonia concentration was decreased from 1792 $\mathrm{mg} / \mathrm{L}$ to $168 \mathrm{mg} / \mathrm{L}$. The linear regression analysis, very efficient method to describe the relationship between independent and the dependent variables, were performed for these data.
\end{abstract}

Keywords: MAP precipitation, leachate, ammonia removal, regression analysis

\section{Introduction}

Sanitary landfills are widely used due to low cost and effectiveness of municipal solid waste disposal in Turkey as well as in other developing countries (Alver and Altaş, 2017; Banar et al., 2006). One of the biggest environmental risks of sanitary landfills is leachate (Renoua et al., 2008; Miao et al., 2019).

Landfill leachate is one of the wastewater types that causes the greatest environmental impact as it contains high amounts of organic compounds, inorganic ions and ammonia nitrogen $\left(\mathrm{NH}_{3}-\mathrm{N}\right)$. Discharge of this wastewater to the receiving environment without proper purification can cause serious pollution in both groundwater aquifers and surface waters. Therefore, the organic compounds and ammonia nitrogen should be removed from the leachate before the leachate is discharged to the receiving waters (He et al., 2014; Huang et al., 2014).

Due to the complex composition and the high pollutant content, many physical chemical and biological treatment methods have been applied to treat the landfill leachate. Among these methods, biological processes are considered to be cost effective and reusable. However, due to the high concentration of ammonia nitrogen and the lack of sufficient electron donors in the leachate, the performance of the conventional activated sludge process used to treat the landfill leachate was not satisfactory (Ozturk et al., 2003; Wanga et al., 2019).

Among the alternative processes, the precipitation of MAP (magnesium ammonium phosphate, $\mathrm{MgNH}_{4} \mathrm{PO}_{4} 6 \mathrm{H} 2 \mathrm{O}$ ) has been shown to be a promising method for the removal of ammonia nitrogen due to its high rate of reaction and removal ratio (Zhang et al., 2009; Di laconi et al., 2010).

MAP is a white insoluble crystalline compound that can occur naturally when the concentrations of $\mathrm{Mg}, \mathrm{NH}_{4}, \mathrm{PO}_{4}$ in solution are higher than the solubility limits (Di laconi et al., 2010).

Due to high toxicity in landfill leachate, nitrogen and phosphorus removal by MAP precipitation seems to be more advantageous than biological methods. In the MAP precipitation, magnesium and phosphorus are added the 
molar concentration equivalent to ammonia, depending on the composition of the wastewater. $\mathrm{MgNH}_{4} \mathrm{PO}_{4} \cdot 6 \mathrm{H}_{2} \mathrm{O}$ precipitate is formed and ammonia is removed (Li et al., 1999; Li and Zhao, 2003).

In this study, ammonia removal from leachate using MAP precipitation method was experimentally investigated and the principles of application of the process were described. At the same time, the linear regression analysis was made for these experiments using Minitab 16.

\section{Material and method}

\subsection{Material}

Experimental study was carried out on samples of landfill leachate taken from Samsun Metropolitan Municipality Sanitary Landfill.

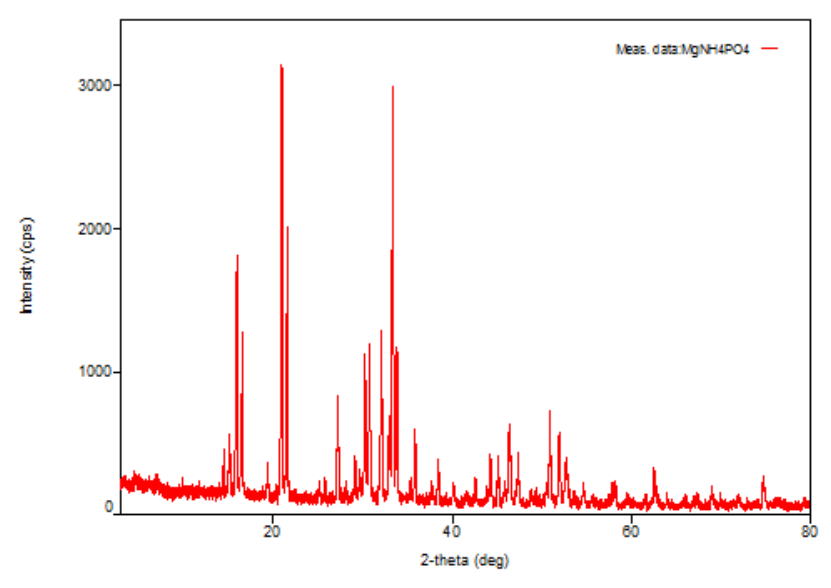

Figure 1. XRD of the MAP precipitates

The characterization of the raw leachate used in the experimental study are given in Table 1 . Ammonia, $\mathrm{pH}, \mathrm{COD}$ and $\mathrm{PO}_{4}-\mathrm{P}$ analysis were carried out for each sample taken during the study and the lowest and highest values are given in the Table 1.

Table 1. Characterization of the landfill leachate used in this study.

\begin{tabular}{ccc}
\hline Parameters & Unit & Range \\
\hline $\mathrm{pH}$ & - & $7.5-8.5$ \\
\hline $\mathrm{NH}_{4}-\mathrm{N}$ & $\mathrm{mg} / \mathrm{L}$ & $1200-1800$ \\
\hline $\mathrm{COD}$ & $\mathrm{mg} / \mathrm{L}$ & $15000-40000$ \\
\hline $\mathrm{PO}_{4}-\mathrm{P}$ & $\mathrm{mg} / \mathrm{L}$ & $20-30$ \\
\hline
\end{tabular}

In the MAP precipitation process, $\mathrm{MgSO}_{4} .7 \mathrm{H}_{2} \mathrm{O}$ was used as the magnesium source, $\mathrm{K}_{2} \mathrm{HPO}_{4}$ was used as the phosphate source, and $6 \mathrm{~N} \mathrm{NaOH}$ was used to increase the $\mathrm{pH}$ of the leachate.

\subsection{Analysis}

The collected MAP precipitates were washed with pure water for three times, dried in an oven at $40{ }^{\circ} \mathrm{C}$ for $48 \mathrm{~h}$, and then analysed by X-ray diffraction (XRD, Rigaku, Smartlab) and scanning electron microscopy with energy dispersive X-ray analysis (SEM-EDS, JEOL JSM-7001F). The results of SEM and XRD are given in Figures 1 and 2 .
The concentrations of $\mathrm{NH}_{4}$ and COD in leachate were measured according Standard Methods (APHA, 1998).

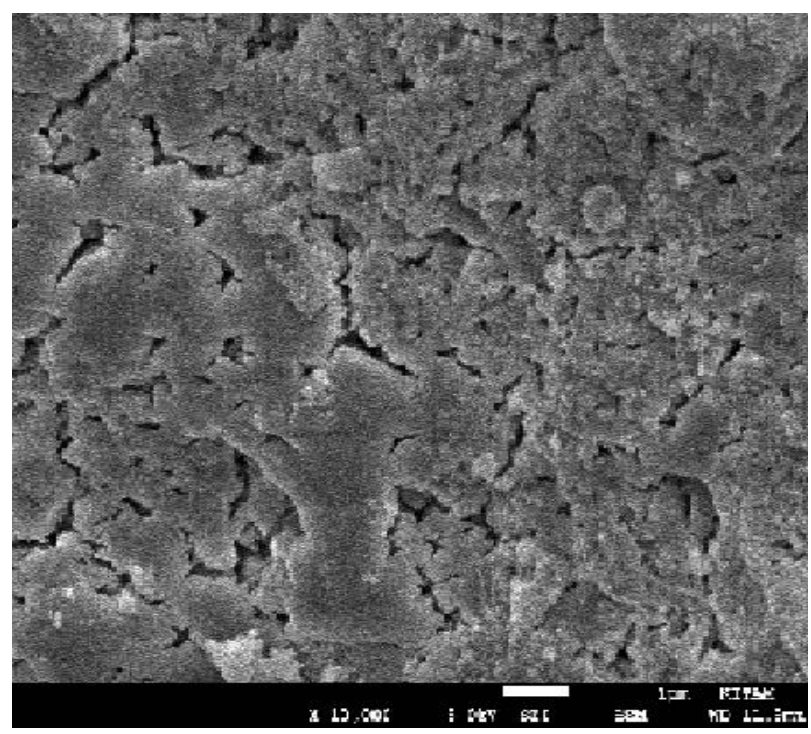

Figure 2. SEM micrograph of the MAP precipitates

\subsection{Experimental study}

The MAP precipitation experiments were carried out on a Velp brand JLT6 model jar test system and, Kjeltec System 1002 Distilling Unit Tecator brand Kjeldahl nitrogen detection device was used for the ammonia nitrogen determination. The experiments were carried out at $\mathrm{pH} 9.5$ and at room temperature.

9 different mixing times have been tested between 2 minutes and 120 minutes with the aim of determining the optimum mixing time in the MAP precipitation process. $\mathrm{NH}_{4}-\mathrm{N}$ and COD analyses were carried out on the samples after stirring at $150 \mathrm{rpm}$ and settling $30 \mathrm{~min}$.

Various mole ratios ( $\mathrm{Mg}: \mathrm{NH}_{4}: \mathrm{PO}_{4}$ ) have been tested for the purpose of achieving the best ammonia and COD removal efficiency by MAP precipitation.

For this purpose, the efficiency of ammonia and COD removal was determined by keeping the others fixed and increasing the $\mathrm{Mg}$ ratio 4 times. The other components were then kept constant and the $\mathrm{PO}_{4}-\mathrm{P}$ ratios were increased up to 2.2 times, after which the ratio of both $\mathrm{Mg}$ and $\mathrm{PO}_{4}-\mathrm{P}$ was increased by keeping the $\mathrm{NH}_{4}-\mathrm{N}$ ratio constant. As a result of the experiments ammonia and COD removal efficiencies were determined.

\subsection{The regression model}

To estimate relationship that relates between dependent variable $(y)$ and independent variables $(x)$, the regression model can be used. Also, the regression model can be determined the mathematical relationship between the dependent and independent variables as a linear, nonlinear, exponential etc. models (http://uregina.ca/ qgingrich/regr.pdf, accessed in 08.13.2018; http:// personal.cb.cityu.edu.hk/msawan/teaching/FB8916/FB89 16Ch1.pdf accessed in 08.13.2018). The most used and the simplest of the regression models is the linear regression 
method. The general linear regression formula can be given as follows,

$$
y_{i}=\beta_{0}+\beta_{1} x_{1}+\beta_{2} x_{2}+\cdots \ldots \beta_{n} x_{n}
$$

In this formula $x_{i}$ is the independent variable and $y_{i}$ is the dependent or response variable, $\beta_{i}$ is coefficients (http://www.mit.edu/ 6.s085/notes/lecture3.pdf, accessed in 08.13.2018).

The linear regression analysis was made for Ammonia and COD removal data by using Minitab 16 in this study.

\section{Results and discussion}

\subsection{Determination of MAP precipitation conditions}

When the results obtained from the characterization study are compared with the literature values, it can be said that the measured concentrations of pollutant parameters are in accordance with the range of values given in the literature.

In the first step of the MAP precipitation experiments, the $\mathrm{Mg}$ ratios were increased, and the other components were kept constant.

At the $\mathrm{Mg}: \mathrm{NH}_{4}: \mathrm{PO}_{4}$ ratio of 1: $1: 0.55,44.83 \%$ ammonia removal was achieved at and COD removal remained at $14.08 \%$. When the $\mathrm{Mg}$ ratio is increased to 4 times, the ammonia and COD removal efficiencies are increased, the increase after the 2.5 times $\mathrm{Mg}$ ratio is not significant. This indicates the saturation of the leachate to the $\mathrm{Mg}$ source.

For ammonia with the highest Mg ratio (4: 1: 0.55), 63.79\% removal was obtained, while for COD, $37.56 \%$ removal was obtained. The experimental results of MAP precipitation, in which the $\mathrm{Mg}$ ratio are increased, and the other components are kept constant, are presented in Figures 3 and 4 .

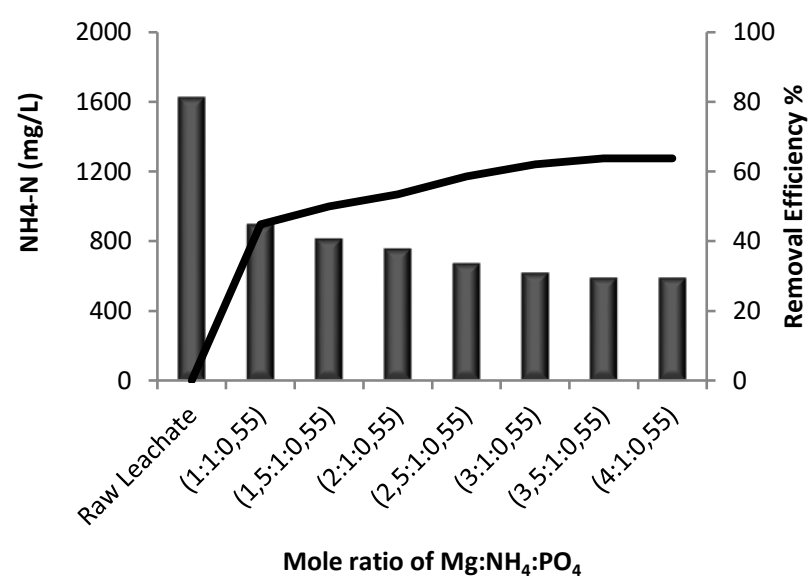

Figure 3. Ammonia removal efficiencies for the MAP precipitation experiment in which the $\mathrm{Mg}$ ratios were increased

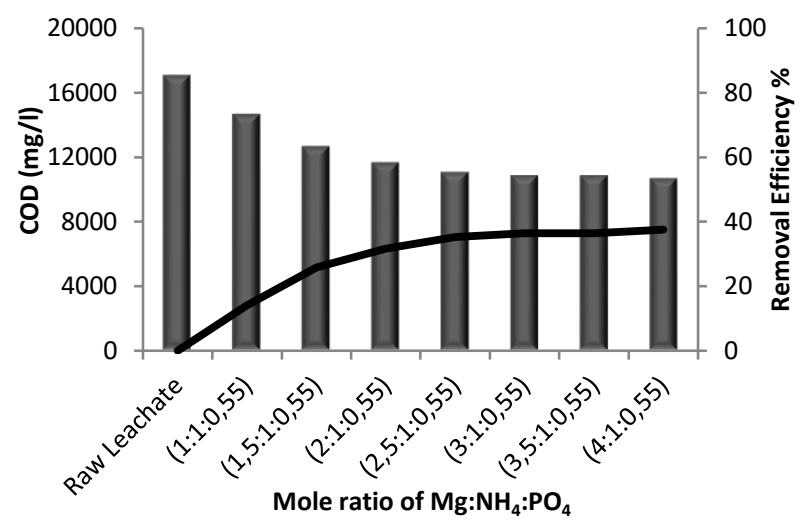

Figure 4. COD removal efficiencies for the MAP precipitation experiment in which the $\mathrm{Mg}$ ratios were increased

In the second step of the MAP precipitation experiments, $\mathrm{PO}_{4}-\mathrm{P}$ ratio was increased and other components were kept constant.

At the $\mathrm{Mg}: \mathrm{NH}_{4}: \mathrm{PO}_{4}$ ratio of $1: 1: 0.55$, the ammonia removal was $37.5 \%$ and the COD removal was $27.60 \%$.

When $\mathrm{PO}_{4}-\mathrm{P}$ ratio was increased up to 2.2 times, a continuous increase in ammonia and COD removal efficiency was observed. This shows that $\mathrm{PO}_{4}-\mathrm{P}$ in the leachate is low and that the leachate is not saturated. The higher $\mathrm{PO}_{4}-\mathrm{P}$ concentrations were not tested in order to avoid higher $\mathrm{PO}_{4}-\mathrm{P}$ concentration in the effluent.

The best ammonia and COD removal efficiency was achieved at $\mathrm{Mg}: \mathrm{NH}_{4}: \mathrm{PO}_{4}$ ratio of 1: 1: 2.2. Ammonia was removed by $81.25 \%$ COD by $35.21 \%$.

Figures 5 and 6 show the results of MAP precipitation experiments in which $\mathrm{PO}_{4}-\mathrm{P}$ ratio is increased and other components are kept constant.

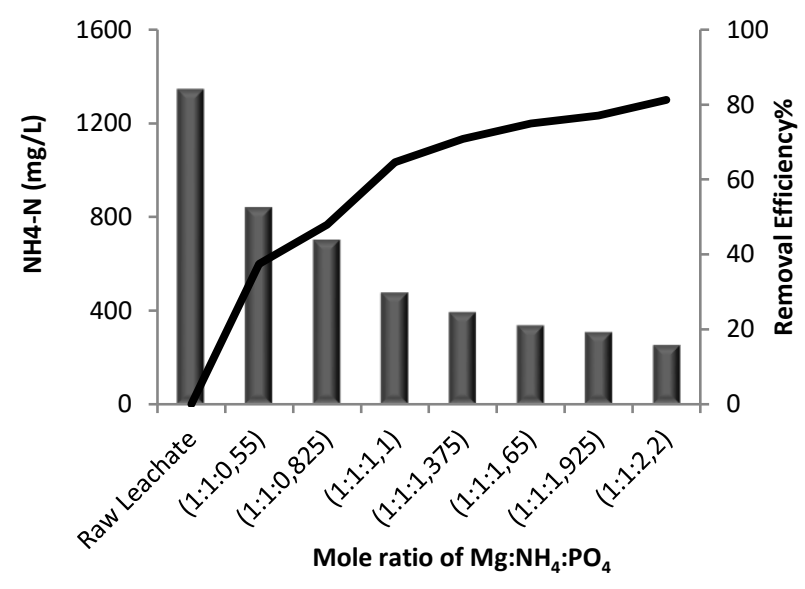

Figure 5. Ammonia removal efficiencies for the MAP precipitation experiment in which the $\mathrm{PO}_{4}-\mathrm{P}$ ratios were increased 


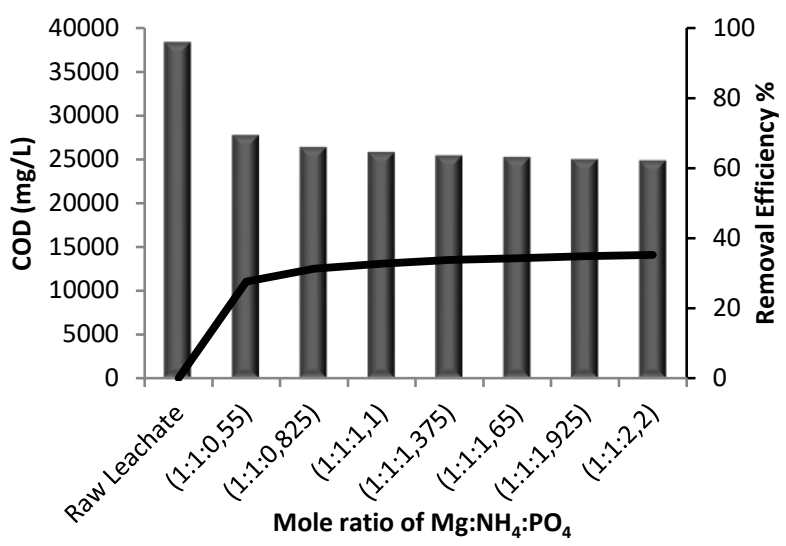

Figure 6. COD removal efficiencies for the MAP precipitation experiment in which the $\mathrm{PO}_{4}$-Pratios were increased

In the third step of the MAP precipitation experiments, both $\mathrm{Mg}$ and $\mathrm{PO}_{4}-\mathrm{P}$ ratios are increased and ammonia concentration is kept constant.

At the $\mathrm{Mg}: \mathrm{NH}_{4}: \mathrm{PO}_{4}$ ratio of 1: $1: 0.55,39.06 \%$ ammonia removal and $26.08 \%$ COD removal were obtained. When both $\mathrm{Mg}$ and $\mathrm{PO}_{4}-\mathrm{P}$ ratios were increased, a steady increase in the removal efficiency was observed.

The highest ammonia and COD removal efficiencies were achieved at $\mathrm{Mg}: \mathrm{NH}_{4}: \mathrm{PO}_{4}$ ratio of $4: 1: 2.2$. At this condition ammonia removal was $90.63 \%$ and COD removal was $39.64 \%$.

Figures 7 and 8 show the results of MAP precipitation experiments in which both $\mathrm{Mg}$ and $\mathrm{PO}_{4}-\mathrm{P}$ ratios are increased and ammonia concentration is kept constant.

\section{The regression analysis}

The Analysis of Variance (ANOVA) is made to determine the dependent variable significant effects on the independent variable. The ANOVA results for ammonia and COD removal experiments were given in Tables 2 and 3.

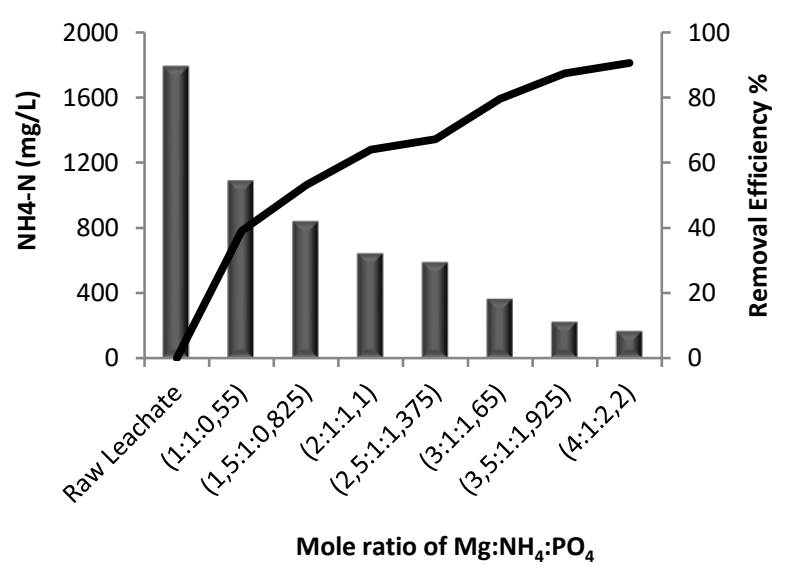

Figure 7. Ammonia removal efficiencies for the experiment of MAP precipitation, in which both $\mathrm{Mg}$ and $\mathrm{PO}_{4}-\mathrm{P}$ ratios were increased

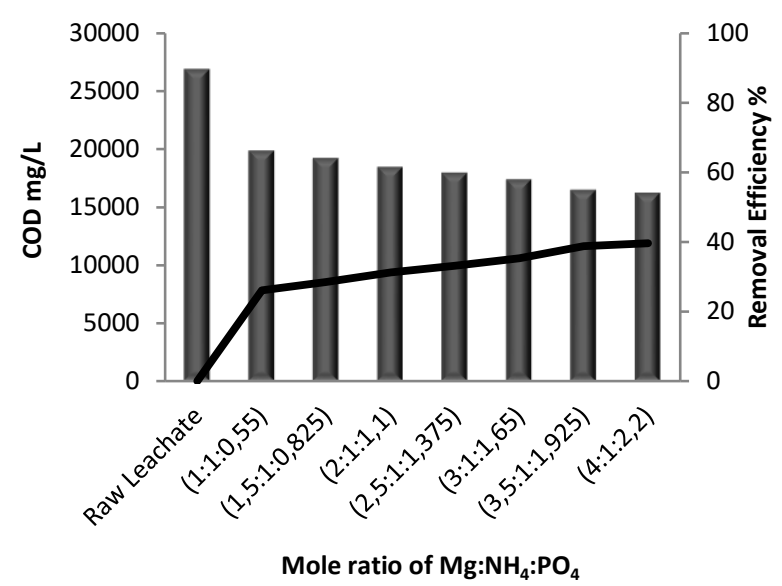

Figure 8. COD removal efficiencies for the experiment of MAP precipitation, in which both $\mathrm{Mg}$ and $\mathrm{PO}_{4}-\mathrm{P}$ ratios were increased

Table 2. The results of ANOVA for ammonia removal.

\begin{tabular}{ccccc}
\hline Source & Adj SS & Adj MS & F-Value & P-Value \\
\hline Regression & 7744.87 & 3872.43 & 189.03 & 0.000 \\
\hline $\mathrm{Mg}$ & 917.85 & 917.85 & 44.80 & 0.000 \\
\hline $\mathrm{PO}_{4}$ & 6165.23 & 6165.23 & 300.95 & 0.000 \\
\hline $\begin{array}{c}\text { Model } \\
\text { Summary }\end{array}$ & S & R-sq & R-sq(adj) & $\begin{array}{c}\text { R- } \\
\text { sq(pred) }\end{array}$ \\
\hline & 4.52614 & $91.53 \%$ & $91.04 \%$ & $89.90 \%$ \\
\hline
\end{tabular}

Table 3. The results of ANOVA for COD removal

\begin{tabular}{ccccc}
\hline Source & Adj SS & Adj MS & F-Value & P-Value \\
\hline Regression & 181.82 & 90.910 & 12.46 & 0.000 \\
\hline $\mathrm{Mg}$ & 159.32 & 159.317 & 21.83 & 0.000 \\
\hline $\mathrm{PO}_{4}$ & 102.75 & 102.748 & 14.08 & 0.001 \\
\hline $\begin{array}{c}\text { Model } \\
\text { Summary }\end{array}$ & S & R-sq & R-sq(adj) & $\begin{array}{c}\text { R- } \\
\text { sq(pred) }\end{array}$ \\
\hline & 2.70158 & $56.73 \%$ & $52.18 \%$ & $46.27 \%$ \\
\hline
\end{tabular}

Then, the linear regression equations of ammonia and COD removal were calculated from these results.

$$
\begin{aligned}
& \text { Ammonia removal }=29.97+4.889 * \mathrm{Mg}+ \\
& 21.53 * \mathrm{PO}_{4} \\
& \text { COD Removal }=22.56+3.399 * \mathrm{Mg}+4.14 * \mathrm{PO}_{4}
\end{aligned}
$$

Finally, the Residual Plots for Ammonia and COD Removal were obtained (Figures 9 and 10).

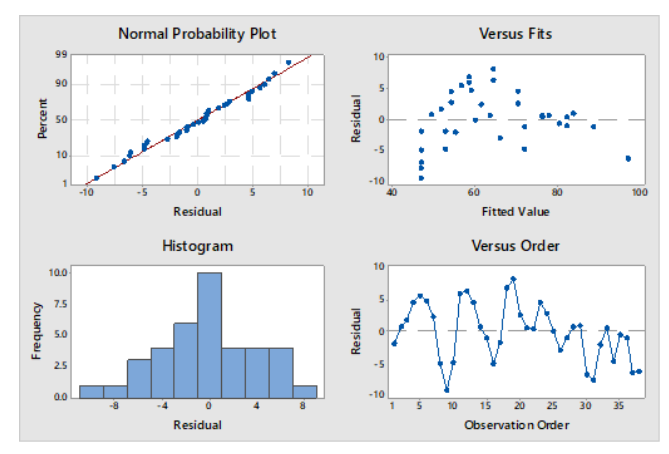

Figure 9. The Residual Plots for Ammonia Removal 


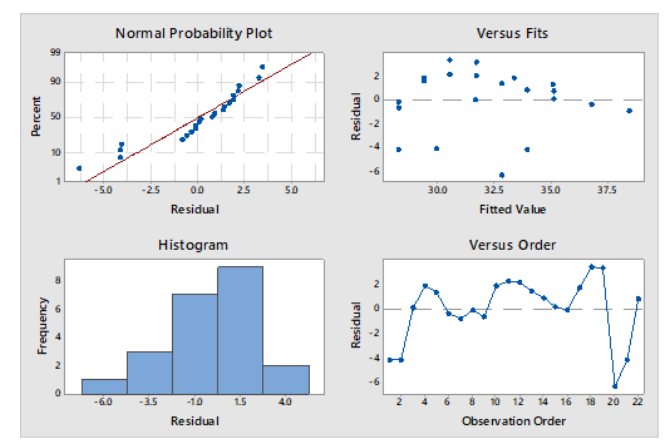

Figure 10. The Residual Plots for COD Removal

\section{Conclusion}

MAP precipitation as a pre-treatment process was used to achieve high ammonia removal from raw leachate collected from sanitary landfill. The removal of ammonia at $\mathrm{Mg}: \mathrm{NH} 4: \mathrm{PO} 4$ ratio of 1: 1: 0.55 varied between $37-44 \%$. The best ammonia removal efficiency ratio was achieved by 90.63\% at $\mathrm{Mg}: \mathrm{NH} 4: \mathrm{PO} 4$ ratio of 4: 1: 2.2. No significant removal of COD was observed during MAP precipitation. For this reason, a biological process should be applied to remove COD. In the experiments, the highest COD removal efficiency was $39.64 \%$.

When applying the MAP precipitation method, attention should be paid to the TDS and $\mathrm{PO}_{4}-\mathrm{P}$ parameters that can remain in the effluent at high concentrations due to the use of chemicals.

It was seen that the different levels of $\mathrm{Mg}$ and $\mathrm{PO}_{4}$ have significant effects on the ammonia and COD removal from the results of statistical analysis. The experiments of Ammonia removal have been described with the linear regression models. The data was very close to the fitted regression line in ammonia removal (91.53\%). On the contrary to the data was not close to the fitted regression line in COD removal (56.73\%). In this case, it can be said that the linear regression model is not suitable for the COD removal data.

\section{Acknowledgment}

This paper was supported by OMU BAP project numbered PYO.MUH.1904.18.003.

\section{References}

Alver A. and Altaş L. (2017), Characterization and electrocoagulative treatment of landfill leachates: A statistical approach, Process Safety and Environmental Protection, 111, 102-111.

APHA (1998), Standard Methods for the Examination of Water and Wastewater, 20th ed., Washington.

Banar M., Özkan A. and Kürkçüoğlu M. (2006), Characterization of the leachate in an urban landfill by physicochemical analysis and solid phase microextraction-GC/MS, Environmental Monitoring Assess, 121, 437-457.

Di laconi C., Pagano M., Ramadori R. and Lopez A. (2010), Nitrogen recovery from a stabilized municipal landfill leachate, Bioresource Technology, 101, 1732-1736.

He S., Zhang Y., Yang M., Du W. and Harada H. (2007), Repeated use of MAP decomposition residues for the removal of high ammonium concentration from landfill leachate, Chemosphere, 66, 2233-2238.

http://personal.cb.cityu.edu.hk/msawan/teaching/FB8916/FB89 16Ch1.pdf accessed in 08.13.2018.

http://uregina.ca/ gingrich/regr.pdf, accessed in 08.13.2018.

http://www.mit.edu/ 6.s085/notes/lecture3.pdf, accessed in 08.13.2018.

Huang H., Xiao D., Zhang Q. and Ding L. (2014), Removal of ammonia from landfill leachate by struvite precipitation with the use of low-cost phosphate and magnesium sources, Journal of Environmental Management, 145, 191-198.

Li X.Z. and Zhao Q.L. (2003), Recovery of ammonium-nitrogen from landfill leachate as a multi-nutrient fertilizer, Ecological Engineering, 20, 171-181.

Li X.Z., Zhao Q.L. and Hao X.D. (1999), Ammonium removal from landfill leachate by chemical precipitation, Waste Management, 19, 409-415.

Miao L., Yang G., Tao T. and Peng Y. (2019), Recent advances in nitrogen removal from landfill leachate using biological treatments - A review, Journal of Environmental Management, 235, 178-185.

Ozturk I., Altinbas M. Koyuncu I., Arikan O. and Yangin Ç.G. (2003), Advanced physico-chemical treatment experiences on young municipal landfill leachates, Waste Management, 23, 441446.

Renoua S., Givaudan J.G., Poulain S., Dirassouyan F. and Moulin P. (2008), Landfill leachate treatment: Review and opportunity, Journal of Hazardous Materials, 150, 468-493.

Wanga Z., Lia J., Tana W., Wua X., Lina H. and Zhanga H. (2019), Removal of COD from landfill leachate by advanced Fenton process combined with electrolysis, Separation and Purification Technology, 208, 3-11.

Zhang T., Ding L. and Ren H. (2009), Pretreatment of ammonium removal from landfill leachate by chemical precipitation, Journal of Hazardous Materials, 166, 911-915. 